\title{
EFFECT OF WATER TEMPERATURE IN DRINKERS AND THEIR LOCATION ON WATER INTAKE BY COWS
}

\author{
Valerii Vtoryi, Sergei Vtoryi, Vladislav Gordeev, Roman Ilin, Victor Khazanov \\ Federal Scientific Agroengineering Centre VIM, Russia \\ vvtoryj@yandex.ru,2vt_1981@list.ru,cow-sznii@yandex.ru, ilinrom@yandex.ru
}

\begin{abstract}
Water temperature in the drinkers and humid environment combined with low or high air barn temperature are equally important factors for cow health, water intake and milk productivity. The study purpose was to determine the water intake by lactating cows from heated drinkers with different location and water temperature and the barn climate in North-West Russia. A group of Holstein dairy cows with loose housing in boxes was selected for the study. Two automatic group drinkers with heating elements were installed in different places in the barn. The experiments had two variants of the drinkers' operation mode. In Variant 1, the heating element in Drinker 1 was switched off, in Drinker 2 - switched on. In Variant 2, the heating elements were switched off in both drinkers. In Variant 1, the difference in the average daily water temperature between Drinker 1 and Drinker 2 was from $4.8^{\circ} \mathrm{C}$ to $6.2{ }^{\circ} \mathrm{C}$, with the average daily air temperature in the barn being from $+11.7^{\circ} \mathrm{C}$ to $+14.8^{\circ} \mathrm{C}$. In this case, the water intake from Drinker 2 with higher, the water temperature was $2.5-5$ times bigger than that from Drinker 1. In Variant 2, the difference in water intake between Drinker 1 and Drinker 2 was 35.1$72.3 \%$. At that time, the average daily air temperature in the barn ranged between $+10.7{ }^{\circ} \mathrm{C}$ and $+14.9{ }^{\circ} \mathrm{C}$. The average daily water temperature in the drinkers was from $+6.3^{\circ} \mathrm{C}$ to $+8.7^{\circ} \mathrm{C}$, with the difference between the drinkers not exceeding $0.8^{\circ} \mathrm{C}$. During the study, the milk yield was from 36.3 to $41.4 \mathrm{~kg} \cdot \mathrm{cow}^{-1}$. day ${ }^{-1}$, with the water intake being from $1.961 \cdot \mathrm{kg}^{-1}$ to $2.481 \cdot \mathrm{kg}^{-1}$. During the experiments, the cow diets did not change. The graphical models based on the experimental data allowed estimating the effect of water temperature on water intake by cows. The study also showed that drinkers' location influenced the water intake. So, when designing the modern drinking systems, more attention is needed to their optimal placement and provision of free access to freshwater for animals at all times.
\end{abstract}

Keywords: cow, watering, milking, automatic drinker, water temperature.

\section{Introduction}

Cows do not consume more water than their physiology requires, as the total amount of water in the animal's body is in a certain balance and depends on external conditions [1]. It should be noted that the water consumed by animals from the drinker can be up to $90 \%$ of the daily body requirement $[2 ; 3]$ and the water comprises $87 \%$ of milk [4].

Research on the water demand of dairy cows was conducted by quite many scientists for different housing conditions in different climatic zones. The season, milk yield, animal weight, diet dry matter content, barn climate, and precipitation are distinguished as the factors to a greater extent affecting the water intake [4-8].

However, water temperature in the drinkers and humid environment combined with low or high air barn temperatures are equally important indicators for cow health, water intake and milk productivity.

The studies $[4 ; 9]$ describe the experiments on heating the drinking water for cows to $+3{ }^{\circ} \mathrm{C},+10{ }^{\circ} \mathrm{C},+17^{\circ} \mathrm{C}$ and $+23{ }^{\circ} \mathrm{C}$. The lowest water intake was at $+23{ }^{\circ} \mathrm{C}$. But at the same time, productivity was higher in cows who drank water heated to $+17^{\circ} \mathrm{C}$ and $+23^{\circ} \mathrm{C}$.

Belarussian researchers noted the effect of water temperature on the drinking pattern of cows and their productivity. At an average water temperature of $+2{ }^{\circ} \mathrm{C}$, the cows visited the drinkers 6.4 times, and at a water temperature of $+12^{\circ} \mathrm{C}$, the number of visits increased to 9.1 times a day. The increase in milk yield at a drinking water temperature of $+12^{\circ} \mathrm{C}$ was $0.9 \mathrm{~kg}[1]$.

The study [3] indicates that water temperature does not significantly affect the drinking behaviour and productivity. If the cows have a choice, they prefer to drink water at a moderate temperature of $+17^{\circ} \mathrm{C}$ to $+28^{\circ} \mathrm{C}$.

Often the freshwater quality and supply on dairy farms are below optimal. It negatively affects animal health and productivity, as well as the farm's economy. The studies were conducted in different countries in Europe, America, and Asia aimed at improving the water use efficiency. The multiple regression equations were developed to predict the drinking water demand and to minimise the dairy farm costs on water supply and distribution systems. These equations were based on experimental data 
and took into account the cow weight and productivity, ambient air temperature and humidity, diet composition and dry matter availability, and some other factors [10-13].

The Russian Federation approved a document [14], which provides for the drinking water intake rate for lactating cows from $4.261 \cdot \mathrm{kg}^{-1}$ to $3.861 \cdot \mathrm{kg}^{-1}$ of milk, depending on the daily milk yield. The drinking water temperature is specified to be from $+8{ }^{\circ} \mathrm{C}$ to $+12{ }^{\circ} \mathrm{C}$ under an ambient temperature of $+10^{\circ} \mathrm{C}$. The norms provide for an increase in the drinking water intake during the warm season. These norms are advisory rather than mandatory; they should be clarified for each subject of the Russian Federation.

This study purpose was to determine the water intake by lactating cows from group drinkers located in different parts of the barn and supplied with heating elements, depending on the water temperature and the barn climate under the conditions of North-West Russia.

\section{Materials and methods}

The experiments were organised in a barn with four sections for loose housing of lactating cows in boxes. A section with a technological group of Holstein cows was chosen for the study (Fig. 1). Two automatic group drinkers made of stainless steel with a capacity of 550 liters each were installed in the section in different places - closer to the feed table and closer to the window. The tilting drinkers were $3 \mathrm{~m}$ long each. The water depth in the drinkers was $35 \mathrm{~cm}$ that may be considered optimal [1].

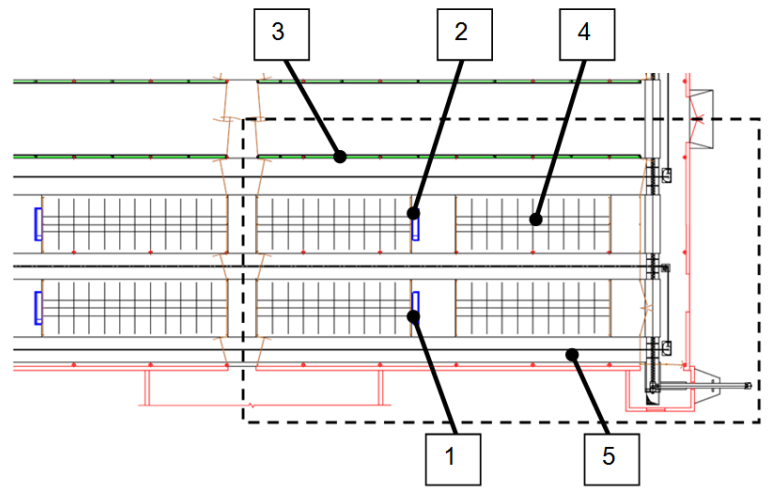

Fig. 1. Diagram of the experimental part of the barn (dotted line): 1 - Drinker 1;

2 - drinker 2; 3 - feed table; 4 - cow boxes; 5 - manure removal scraper

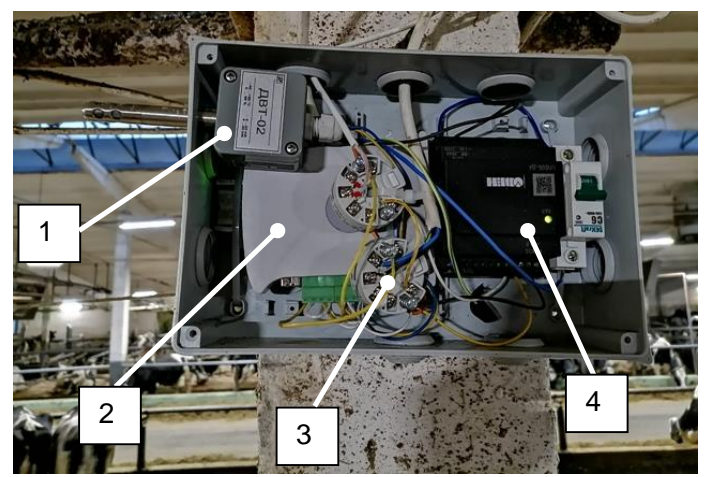

Fig. 2. Recording block of indoor climate parameters and water temperature in

drinkers: 1 - air temperature and relative humidity sensor; 2 - data achiever; 3 - signal converter from the temperature sensor in the drinker; 4 - power unit

To heat the water, $1.5 \mathrm{~kW}$ heating elements were installed in the drinkers. The experiments had two variants of the drinker operation mode. In Variant 1, the heating element in Drinker 1 was switched off, in Drinker 2 - switched on. In Variant 2, the heating elements were switched off in both drinkers.

Fig. 2 shows a recording block for the barn air parameters and water temperature in the drinkers. It was located directly near the drinkers at a height of 2.0 meters. The block included a DVT-02 temperature sensor with the measuring range from $-40{ }^{\circ} \mathrm{C}$ to $+85^{\circ} \mathrm{C}$ and measurement error of $\pm 1{ }^{\circ} \mathrm{C}$; a humidity sensor with the measuring range from 0 to $100 \%$ and measurement error of $\pm 3 \%$; an MSD200 data archiver, an NPT-3.00.1.2 analogue signal converter, with the conversion error being less than $\pm 0.5 \%$, and a BP $60 \mathrm{~K}$ power unit. All devices and sensors were of Russian manufacture.

DTS-314-100M water temperature sensor with the measuring range from $-50{ }^{\circ} \mathrm{C}$ to $+150{ }^{\circ} \mathrm{C}$ was installed in the float chamber of the drinker. Ambient parameters and water temperatures were recorded automatically every 10 minutes and archived on an external storage medium. An electronic water flow meter DU-15 [6] was mounted directly on the water pipe leading to the drinker. It recorded the data on water intake by animals every hour and loaded it to its internal memory.

The cows were milked three times on a parallel milking installation. Drinking water intake and milk yields were recorded for the whole group and average values per animal were calculated. 
To compare the experimental data and the calculated values of water intake by cows, the regression equations were applied - equation (1) from [15] and equation (2) from [6]:

$$
\begin{gathered}
P_{1}=-27.93+0.49 T+3.15 M, R^{2}=0.67 \\
P_{2}=0.023 T^{3}-0.805 T^{2}+9.944 T+40.25, R^{2}=0.609
\end{gathered}
$$

where $P_{1}, P_{2}-$ water intake, $1 \cdot$ cow $^{-1} \cdot$ day $^{-1}$;

$M$ - milk yield, $\mathrm{kg} \cdot \mathrm{day}^{-1}$;

$T$ - average air temperature in the barn, ${ }^{\circ} \mathrm{C}$;

$R^{2}$ - determination coefficient.

Microclimate parameters were considered through the temperature-humidity index (THI), which characterised the comfort conditions for animals and was calculated by the equation (3) from [16;17]:

$$
T H I=(1.8 t+32)-(0.55-0.0055 R H)(1.8 t-26)
$$

where $t$-air temperature, ${ }^{\circ} \mathrm{C}$;

$R H$ - relative humidity, \%.

This indicator is more typical for the warm season, yet its use is convenient and informative [18]. THI $<71$ shows no heat stress or a "comfort zone", while THI from 72 to 79 shows moderate heat stress $[16 ; 19]$.

The dry matter content in the diet has a significant effect on the total water intake [5]. The cows in the study group received a complete feed mixture with a dry matter content of $27.0 \pm 0.4 \mathrm{~kg} \cdot \mathrm{cow}^{-1}$. The diet did not change over the entire study period. Feed was distributed twice a day at the feed table by a mobile feed dispenser at 07-00 and 14-00.

Statistical averages and values for charting were calculated in Microsoft Office Excel 2010.

\section{Results and discussion}

Table 1 and Table 2 show the study results by two variants of the drinker operation mode. Two time periods were selected for consideration - from 20 to 30 November 2020 and from 15 to 25 January 2021. They were characterised by the low influence of such factors as weather, the same diet throughout the study period, and the constant number of animals in the group $-86 \pm 2$. The average daily outdoor air temperature was $-7.3{ }^{\circ} \mathrm{C}$ for Variant 1 and $-5.0^{\circ} \mathrm{C}$ for Variant 2 ; the relative humidity was $90 \%$ and $92 \%$, respectively, and the wind speed was $1.8 \mathrm{~m} \cdot \mathrm{s}^{-1}$ and $1.5 \mathrm{~m} \cdot \mathrm{s}^{-1}$, respectively.

\begin{tabular}{|c|c|c|c|c|c|}
\hline Date & $\begin{array}{l}\text { Animals in } \\
\text { the study } \\
\text { group }\end{array}$ & 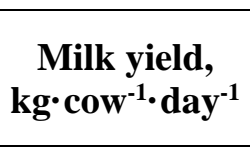 & $\begin{array}{c}\text { Barn } \\
\text { temperature, } \\
{ }^{\circ} \mathrm{C} \\
\end{array}$ & $\begin{array}{c}\text { Barn air } \\
\text { humidity, } \\
\%\end{array}$ & $\begin{array}{c}\text { Overall water } \\
\text { intake, } \\
\text { l- } \text { cow }^{-1} \cdot \text { day }^{-1}\end{array}$ \\
\hline 20.11 .2020 & 86 & 39.3 & $13.0 \pm 2.6$ & $88.5 \pm 7.0$ & 80.93 \\
\hline 21.11 .2020 & 86 & 38.5 & $12.1 \pm 2.3$ & $84.3 \pm 7.0$ & 83.72 \\
\hline 22.11 .2020 & 86 & 38.9 & $12.1 \pm 2.8$ & $91.2 \pm 9.8$ & 83.72 \\
\hline 23.11 .2020 & 86 & 39.9 & $14.8 \pm 1.8$ & $94.8 \pm 8.6$ & 94.88 \\
\hline 24.11 .2020 & 86 & 39.7 & $13.4 \pm 2.8$ & $91.6 \pm 6.6$ & 89.30 \\
\hline 25.11 .2020 & 86 & 40.4 & $12.2 \pm 3.0$ & $83.3 \pm 8.2$ & 86.51 \\
\hline 26.11 .2020 & 85 & 41.0 & $13.8 \pm 3.2$ & $92.2 \pm 9.5$ & 93.18 \\
\hline 27.11 .2020 & 85 & 40.5 & $12.3 \pm 2.5$ & $88.8 \pm 5.3$ & 98.82 \\
\hline 28.11 .2020 & 85 & 40.9 & $12.7 \pm 1.5$ & $89.6 \pm 7.9$ & 90.35 \\
\hline 29.11 .2020 & 85 & 41.4 & $12.1 \pm 1.3$ & $80.4 \pm 7.8$ & 84.71 \\
\hline 30.11 .2020 & 85 & 41.1 & $11.7 \pm 1.0$ & $79.6 \pm 5.3$ & 87.53 \\
\hline
\end{tabular}

Table 1

Experimental data of Variant 1 from 20 to 30 November 2020

In our study, THI index calculated by equation (3) was in the "comfort zone" for animals. It was $56.1 \pm 2.5$ from 20 to 30 November 2020 and $55.2 \pm 3.4$ - from 15 to 25 January 2021 . 
Experimental data of Variant 2 from 15 to 25 January 2021

Table 2

\begin{tabular}{|c|c|c|c|c|c|}
\hline Date & $\begin{array}{c}\text { Animals in } \\
\text { the study } \\
\text { group }\end{array}$ & 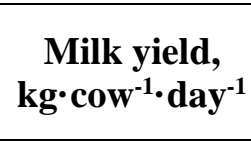 & $\begin{array}{c}\text { Barn } \\
\text { temperature, } \\
{ }^{\circ} \mathrm{C}\end{array}$ & $\begin{array}{c}\text { Barn air } \\
\text { humidity, } \\
\%\end{array}$ & $\begin{array}{c}\text { Overall water } \\
\text { intake, } \\
\text { l·cow }{ }^{-1} \cdot \text { day }^{-1}\end{array}$ \\
\hline 15.01 .2021 & 88 & 38.0 & $10.7 \pm 2.7$ & $91.7 \pm 9.8$ & 76.96 \\
\hline 16.01 .2021 & 88 & 37.9 & $12.0 \pm 3.8$ & $97.0 \pm 5.4$ & 77.51 \\
\hline 17.01 .2021 & 88 & 38.4 & $12.5 \pm 3.7$ & $94.5 \pm 8.2$ & 75.22 \\
\hline 18.01 .2021 & 88 & 38.1 & $11.8 \pm 2.5$ & $90.6 \pm 6.3$ & 85.76 \\
\hline 19.01.2021 & 88 & 37.8 & $13.2 \pm 2.3$ & $93.4 \pm 7.7$ & 78.79 \\
\hline 20.01 .2021 & 88 & 38.1 & $13.5 \pm 2.7$ & $93.7 \pm 9.9$ & 81.99 \\
\hline 21.01 .2021 & 88 & 39.0 & $11.8 \pm 1.9$ & $87.7 \pm 8.9$ & 90.77 \\
\hline 22.01 .2021 & 88 & 38.5 & $11.9 \pm 2.8$ & $88.7 \pm 10.9$ & 79.50 \\
\hline 23.01.2021 & 88 & 36.9 & $14.5 \pm 2.5$ & $94.0 \pm 10.7$ & 91.40 \\
\hline 24.01 .2021 & 88 & 36.3 & $13.7 \pm 1.9$ & $89.9 \pm 10.5$ & 79.32 \\
\hline 25.01 .2021 & 88 & 37.8 & $14.9 \pm 2.3$ & $93.3 \pm 10.4$ & 80.86 \\
\hline
\end{tabular}

During the period from 20 to 30 November 2020, the average milk yield was $38.5-41.4 \mathrm{~kg} \cdot \mathrm{cow}^{-1} \cdot \mathrm{day}^{-1}$, with the average water intake being of $2.05-2.441 \cdot \mathrm{kg}^{-1}$ of milk. During the period from 15 to 25 January 2021 , the average milk yield was $36.3-39.0 \mathrm{~kg} \cdot \mathrm{cow}^{-1} \cdot \mathrm{day}^{-1}$, with the average water intake being of $1.96-2.48 \mathrm{l} \cdot \mathrm{kg}^{-1}$ of milk.

Figure 3 and Figure 4 show the comparison of water intake in two drinkers in the selected study periods per animal per day.

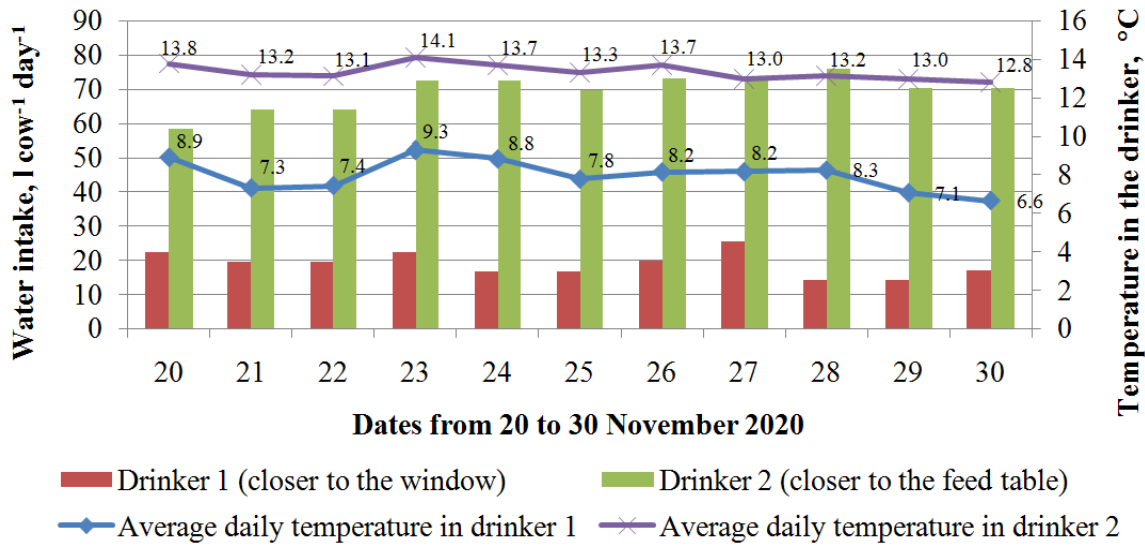

Fig. 3. Water intake from two drinkers, $1 \cdot \operatorname{cow}^{-1} \cdot$ day $^{-1}$, from 20 to 30 November 2020

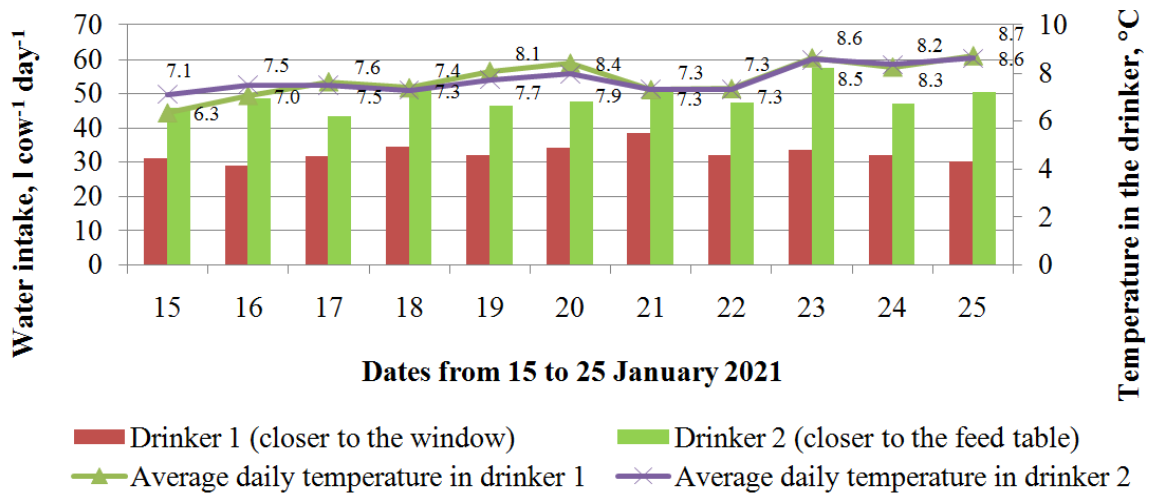

Fig. 4. Water intake from two drinkers, $1 \cdot \operatorname{cow}^{-1} \cdot$ day $^{-1}$, from 15 to 25 January 2021

In Variant 1, the difference in the average daily water temperature between Drinker 1 and Drinker 2 was from $4.8^{\circ} \mathrm{C}$ to $6.2^{\circ} \mathrm{C}$ (Fig. 3), with the average daily air temperature in the barn being from $+11.7^{\circ} \mathrm{C}$ to $+14.8^{\circ} \mathrm{C}$. In this case the water intake from Drinker 2 with higher water temperature 
was 2.5-5 times bigger than that from Drinker 1 (Fig.3). Fig. 5 compares the experimental data and calculated values by equations (1) and (2). The discrepancy in water intake by cows between the experimental and calculated values was from $6.9 \%$ to $27.9 \%$ by equation (1) and from $-11.3 \%$ to $5.8 \%$ by equation (2).

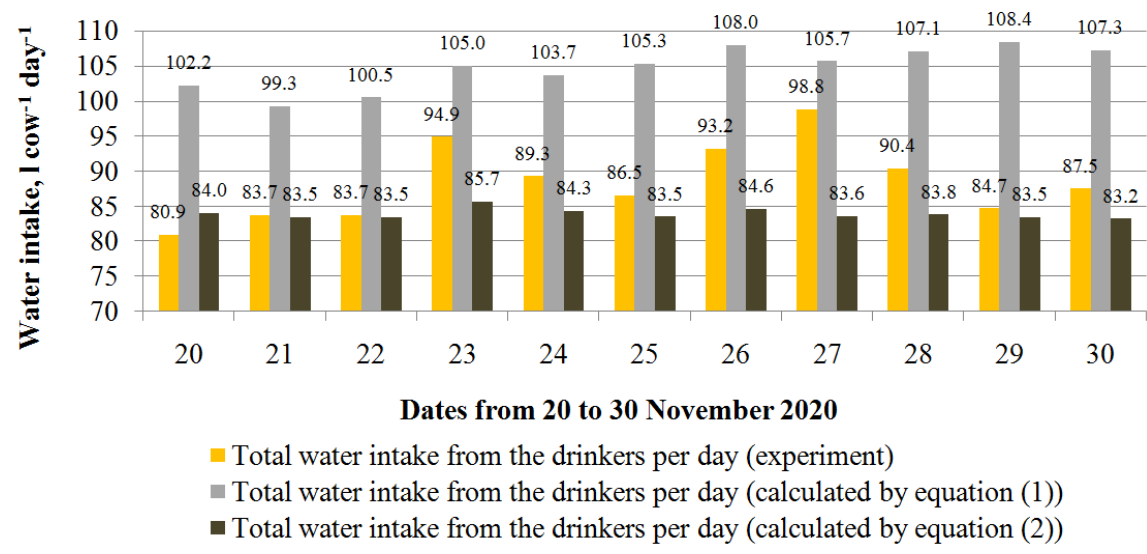

Fig. 5. Comparison of the experimental and calculated total water intake by Variant 1 from 20 to 30 November 2020

In Variant 2, the difference in water intake between Drinker 1 and Drinker 2 was from $35.1 \%$ to $72.3 \%$ (Fig.4). The average daily air temperature in the barn ranged between $+10.7^{\circ} \mathrm{C}$ and $+14.9^{\circ} \mathrm{C}$. The average daily water temperature in the drinkers was from $+6.3^{\circ} \mathrm{C}$ to $+8.7^{\circ} \mathrm{C}$, with the difference between the drinkers not exceeding $0.8^{\circ} \mathrm{C}$ (Fig. 4). Comparison of experimental and calculated values of water intake by cows was from $4.4 \%$ to $31.8 \%$ by equation (1) and from $-8.2 \%$ to $11.3 \%$ by equation (2) (Fig. 6).

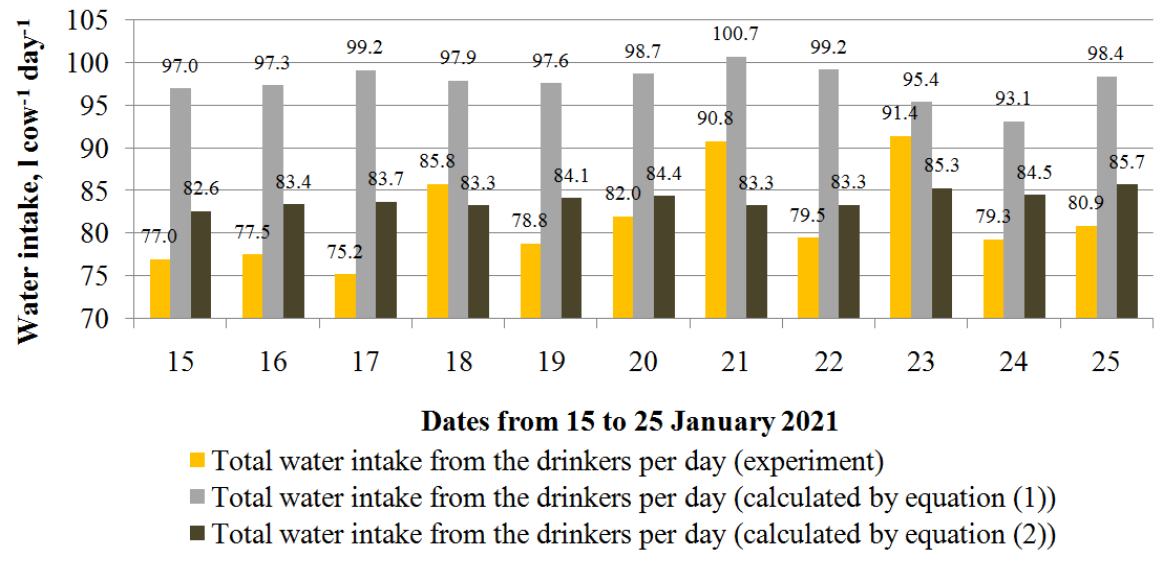

Fig. 6. Comparison of the experimental and calculated total water intake by Variant 2 from 15 to 25 January 2021

The diagrams in Fig. 3 and Fig. 4 show that throughout the experiments, the cows preferred to visit Drinker 2 regardless of the drinker operation mode. This is largely due to its closer location to the feed table.

Comparison of the experimental and calculated values by equations (1) and (2) showed the discrepancy in water intake by cows to range from $-11.3 \%$ to $31.8 \%$. This is due to different temperature and humidity conditions in the barns, the water temperature in the drinkers, different level of cows' productivity and other factors, for which the equations were obtained. This is confirmed by low values of $R^{2}=0.67$ by equation (1) and 0.609 by equation (2). When predicting the water intake at a particular farm, the animal housing and servicing system should be considered, as well as the effect of the weather conditions on the barn indoor climate. 


\section{Conclusions}

The study demonstrated that in cold months, when the barn air temperature was from $+10.7^{\circ} \mathrm{C}$ to $+14.8^{\circ} \mathrm{C}$ and $\mathrm{THI}$ index $=51.8-58.6$, showing comfortable conditions for animals, the water temperature in the drinkers and the location of the drinkers relative to the feed table had a significant effect on the water intake of lactating cows. With a difference in the average daily water temperature between the drinkers from $4.8^{\circ} \mathrm{C}$ to $6.2^{\circ} \mathrm{C}$, the water intake by cows from the drinker with warmer water was 2.5-5.0 times higher compared to the drinker with colder water. When the water temperature in the drinkers was the same, the animals visited the drinker located closer to the feed table more often.

During the experiment from 20 to 30 November 2020, the average milk yield was 38.5-41.4 $1 \cdot \mathrm{cow}^{-1} \cdot \mathrm{day}^{-1}$, with the average water intake being $2.05-2.441 \cdot \mathrm{kg}^{-1}$ of milk. During the experiment from 15 to 25 January 2021, the average milk yield was $36.3-39.01 \cdot \mathrm{cow}^{-1} \cdot$ day $^{-1}$, with the average water intake being $1.96-2.481 \cdot \mathrm{kg}^{-1}$ of milk.

The study also showed that the drinker location in the section influenced the water consumption. The study emphasises the need to pay more attention to the optimal placement of drinkers and organising free access to water for animals at any time when designing the modern drinking systems.

\section{References}

[1] Шматко Н.Н., Музыка А.А., Кирикович С.А., Москалёв А.А., Тимошенко М.В. Водообеспечение коров на селекционно-племенной молочной ферме (Water supply for cows at a breeding dairy farm). Зоотехническая наука Беларуси: Zootechnical science of Belarus. 2016. No. 2. pp. 325-333. (In Russian)

[2] Harner J.P., Brouk M.J., Potts J., Bradford B., Smith J. F. Scientific data for developing water budgets on a dairy. Proceedings of Western Dairy Management Conference, March 6-8 Reno, NV.2013, pp. 90-104.

[3] Looper M.L., Waldner D.N. Water for Dairy Cattle. Las Cruces, New Mexico State University, 2002. 8 p. [online] [28.02.2021] Available at: https://aces.nmsu.edu/pubs/_d/D107.pdf

[4] Beede D. The Most Essential Nutrient: Water. Proceedings of Western Dairy Management Conf., March, 2005. [online] [28.02.2021] Available at:

https://www.researchgate.net/publication/228393898_The_Most_Essential_Essential_Nutrient_W ater.

[5] Khaskheli A.A. Influence of dietary manipulations and milking frequency on production of dairy cows. Online J. Anim. Feed Res. 2020. 10(4). pp. 115-119 DOI: 10.51227/ojafr.2020.25

[6] Vtoryi V., Vtoryi S., Gordeev V., Khazanov V., Ilyin R. Water consumption for cow watering under loose housing system. Proceedings of the 19th International Scientific Conference "Engineering for rural development" May 20-22, 2020, Jelgava, Latvia. pp. 518-524. DOI:10.22616/ERDev.2020.19.TF118

[7] Normando S., Mantovani R., Gabai G. Behavioural, phusiological and productive effects of water unavailability as a form of unpredictable management stressor in dairy cows. Large Animal Review. 2016. 4. pp. 153-159.

[8] Khaskheli A.A. Dairy cows under the influence of dietary manipulations: A-Review. Scientific Journal of Animal and Veterinary Science. 2020. 2(1). pp. 01-07.

[9] Axegärd C. Individual drinking water intake of dairy cows in an AMS barn. 2017. [online] [28.02.2021] Available at: https://stud.epsilon.slu.se/10295/

[10] Khelil-Arfa H., Boudon A., Maxin G., Faverdin P. Prediction of water intake and excretion flows in Holstein dairy cows under thermoneutral conditions. Animal, 2012.Vol. 6(10). pp. 1662-1676. DOI: $10.1017 /$ S $175173111200047 X$

[11] Appuhamy J. A. D. R. N., Judy J. V., Kebreab E., and Kononoff P. J. Prediction of drinking water intake by dairy cows. Journal of Dairy Science. 2016. Vol. 99. No. 9. pp. 7191-7205. DOI: 10.3168/jds.2016-10950

[12] Shine P., Murphy M., Upton J. A Global review of monitoring, modeling, and analyses of water demand in dairy farming. Sustainability. 2020. 12(17). pp. 1-20. DOI:10.3390/su12177201

[13] Cardot V., Le Roux Y., Jurjanz S. Drinking behavior of lactating dairy cows and prediction of their water intake. Journal of Dairy Science. 2008. Vol. 91, 6. pp. 2257-2264. DOI: 10.3168/jds.20070204 
[14] РД-АПК 1.10.01.01-18. Методические рекомендации по технологическому проектированию ферм и комплексов крупного рогатого скота (Management Directive for Agro-Industrial Complex. Recommendations on technological designing of cattle farms and complexes). Moscow: Rosinformagrotech: М.: Росинформагротех. 2018. 166 p. (In Russian)

[15] Krauß M., Drastig K., Prochnow A., Rose-Meierhöfer S., Kraatz S. Drinking and cleaning water use in a dairy cow barn. Water. 2016. 8(7), 302. DOI:10.3390/w8070302

[16] Levit H., Pinto S., Amon T., et al. Dynamic cooling strategy based on individual animal response mitigated heat stress in dairy cows. Animal. 2021. 15(2): 100093. DOI: 10.1016/j.animal.2020.100093.

[17] Le Riche E., Vander Zaag A., Burtt S., Lapen D., Gordon R. Water use and conservation on a freestall dairy farm. Water. 2017. 9(12). 977. DOI:10.3390/w9120977

[18] Mylostyvyi R., Izhboldina O. Climate assessment in modern sustainable cattle barns using temperature-humidity index. New stages of development of modern science in Ukraine and EU countries: monograph. 2019. pp.124-144. DOI: 10.30525/978-9934-588-15-0-134.

[19] Nejad J.G., Lohakare J.D., West J.W., Kim W., Lee B.H., Sung K.I. Effects of water restriction following feeding on nutrient digestibilities, milk yield and composition and blood hormones in lactating Holstein cows under heat stress conditions. Italian Journal of Animal Science. 2015. 14(3). pp. 479-483. DOI:10.4081/ijas.2015.3952 